\title{
Perception of Nigerian Lecturers on Usefulness, Ease of Use and Adequacy of Use of Digital Technologies for Research Based on University Ownership
}

\author{
Samuel Nathaniel ${ }^{1^{\star}}\left(\mathbb{D}\right.$, Semiu Olawale Makinde ${ }^{2^{\star \star}}$ (D) , Oyeronke Olufunmilola Ogunlade ${ }^{1}(\mathbb{C}$
}

${ }^{1}$ University of Ilorin, Ilorin NIGERIA

${ }^{2}$ Al-Hikmah University, Ilorin NIGERIA

*Corresponding Author: nathanielsamuel09@yahoo.com

**Corresponding Author: osmakintoch1@gmail.com

Citation: Nathaniel, S., Makinde, S. O., \& Ogunlade, O. O. (2021). Perception of Nigerian Lecturers on Usefulness, Ease of Use and Adequacy of Use of Digital Technologies for Research Based on University Ownership. International Journal of Professional Development, Learners and Learning, 3(1), ep2106. https://doi.org/10.30935/ijpdll/10881

\begin{abstract}
This paper investigated the perception of Nigerian lecturers on usefulness, ease of use and adequacy of use of digital technologies for research based on university ownership. The use of digital technologies for research in the 21st century for ease and access of information cannot be underscored irrespective of lecturers' university ownership. The study was descriptive of survey type using structured questionnaire to elicit response from the respondents. A total of 742 respondents were drawn purposively from 13 public comprising state and federal universities in Southwest, Nigeria. The research instrument was validated by 3 educational technologists and the reliability indices of $\mathrm{r}=0.92,0.85$ and 0.83 using Cronbach Alpha was attained on perceived usefulness, ease of use and adequacy of use of digital technologies respectively for research at 0.05 level of significance. Frequency counts, means and percentages were used to answer research questions 1-3, while 3 research hypotheses were tested using independent t-test statistical instrument. The finding revealed that lecturers in the federal government owned universities exemplified high perception on the usefulness and ease of use of digital technologies. However, lecturers from state government owned universities perceived adequacy of use of digital technologies for accomplishing research task effectively with minimum error. The study among others provision of institutional support, procurement of needed digital technologies and internet facilities, seminars, workshops and trainings to all university lecturers on usefulness, ease of use of newer digital technologies and skills to possess in accomplishing research task effectively with minimum error; irrespective of university ownership.
\end{abstract}

Keywords: university ownership, digital technologies, ownership, perception

Received: 6 Nov. 2020 Accepted: 1 Jan. 2021

\section{INTRODUCTION}

The avid thirst for knowledge via electronic resources and common parlance of "publish or perish" in academic community compelled lecturers to employ the use of Information and Communication Technologies (ICTs) for academic research. University system is anchored on efficient production of quality graduates with abilities, competences and employability skills for effective job delivery that will facilitate national development and growth; (Udoh-Uwah \& Etim, 2018); through trained academic staff that has considerable knowledge research publications, organization of seminars and mentorship programmes. Newer digital technologies are more often used in facilitating speedy and dissemination research findings in form of research publications anywhere and anytime (Samuel, 2016). Ogunjobi and Fagbami (2012) attested that the usefulness of digital technologies and internet facilities are capable of providing Nigerian researchers and scholars with the enabling environment (ease of use) of overcoming obstacles to communication and collaboration (adequacy of use) and presentation of research findings with ease across the globe. Famurewa (2014), and Halidu (2015) found out that underfunding of Nigerian state universities has effects of: inaccessibility to research grants, inadequate internet and ICT facilities, ill-equipped libraries and poor manpower training and development on the lecturers' productivity vis-à-vis academic research publication. Abba and Lamido - Gora (2019) found out that the level of university lecturers' proficiency and usefulness of digital and internet facilities are major factors that encouraged them to frequently access electronic resources for dissemination of academic finding via publication. Hence, the use of newer technologies to access and disseminate research findings becomes very paramount tools to university academic staff in the 21 st century system of education. University education system in Nigeria includes public and private universities (as shown in Figure 1). 


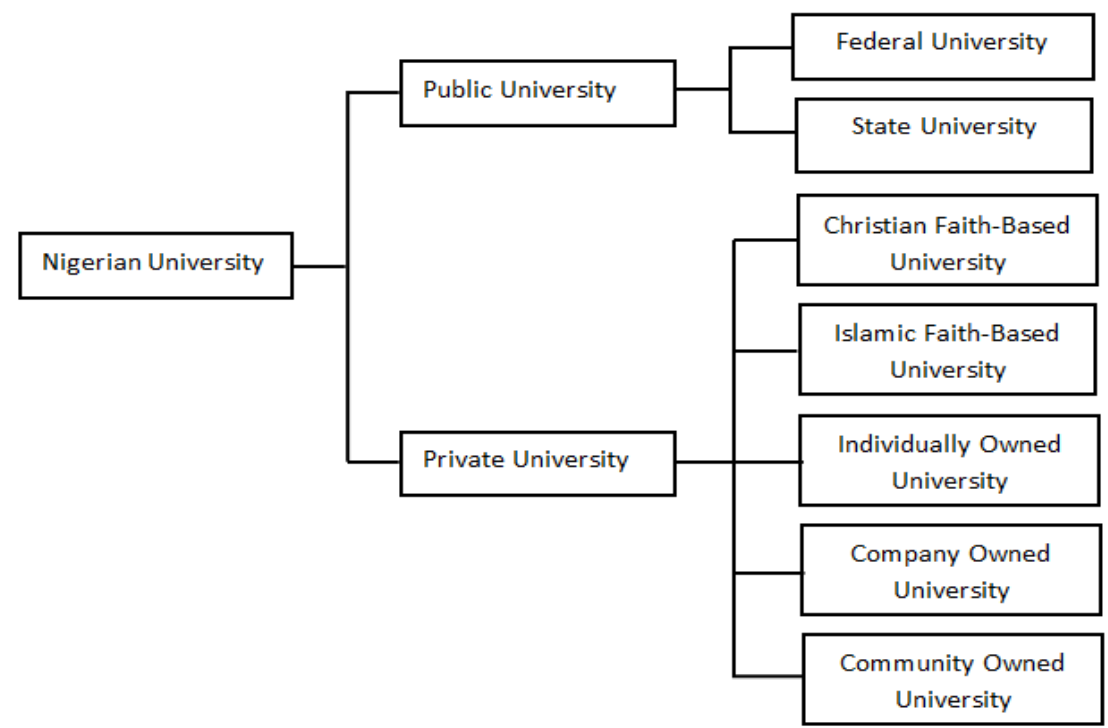

Figure 1. Ownership Classification of Universities in Nigeria

Source: NUC, 2019; Mogaji, (2019)

Table 1. Nigerian Universities across the Six Geo-political Zones as approved as at August 1st 2019

\begin{tabular}{ccccc}
\hline Geo-political Zones & Federal & State & Private & Total \\
\hline South-west & 7 & 11 & 36 & 54 \\
\hline South-south & 7 & 10 & 14 & 31 \\
\hline North-central & 7 & 6 & 11 & 24 \\
\hline South-East & 5 & 10 & 13 & 28 \\
\hline North-west & 10 & 8 & 3 & 21 \\
\hline North-east & 7 & 7 & 2 & 16 \\
\hline Total & $\mathbf{4 3}$ & $\mathbf{5 2}$ & $\mathbf{7 9}$ & $\mathbf{1 7 4}$ \\
\hline
\end{tabular}

Source: Mogaji (2019)

Public universities are run by both federal and state governments while private universities are owned and manage by different organizations, individuals and religious bodies (Mogaji, 2019) irrespective of geographical zone. Table 2 contained Nigerian universities across the six geo-political zones as approved as by the National University Commission at August 1st 2019.

According to the information available on the NUC websites as of August 1st, 2019, there are currently 174 approved universities in Nigeria. As presented in Table 1, it comprises of 43 federal universities, 52 state universities and 79 private universities (NUC, 2019; Mogaji, 2019). The Nigerian public universities were established, controlled and funded by the government by providing the needed infrastructural facilities (Mogaji, 2019); hence, each state in Nigeria could brag of a university for economy and educational development of its catchment environment. Consequently, federal universities are under the control of the Federal Ministry of Education, funded than the state universities, located in each of the six geo-political zones of Nigeria and to facilitate access to educational development of every citizen of the country irrespective of the tribe and geopolitical zone such comes from. However, state universities lacked adequate human and non-human resources and financial backing that could facilitate better productivity of both staff and students (Mogaji, 2019). The resultant effects of underfunding related problems confronting state owned universities are seen in the publication academic researches being the backbone for economic and technological advancement of any nation of the world.
Table 2. Breakdown of South-west Geopolitical Zone each State, and the numbers of Universities available in each state

\begin{tabular}{cccccc}
\hline $\begin{array}{c}\text { Geographical } \\
\text { Zone }\end{array}$ & State & Federal & State & Private & Total \\
\hline \multirow{7}{*}{ South-west } & Ekiti & 1 & 1 & 1 & 3 \\
\cline { 2 - 6 } & Lagos & 2 & 1 & 5 & 8 \\
\cline { 2 - 6 } & Ogun & 1 & 2 & 12 & 15 \\
\cline { 2 - 6 } & Ondo & 1 & 3 & 3 & 7 \\
\cline { 2 - 6 } & Osun & 1 & 2 & 8 & 11 \\
\cline { 2 - 6 } & Oyo & 1 & 2 & 7 & 10 \\
\hline Total & & $\mathbf{7}$ & $\mathbf{1 1}$ & $\mathbf{3 6}$ & $\mathbf{5 4}$ \\
\hline
\end{tabular}

Source: Mogaji (2019)

Table 2 presents the breakdown of each state in the South-west geopolitical zones and the numbers of universities in each state.

The geographical location of these universities is further classified into 6 geopolitical zones - South West, South-South, North Central, South East, North West and North East. South-west (Ekiti, Lagos, Ogun, Ondo, Osun and Oyo) has the highest number of State and Private Universities. The Zone has 11 state Universities and 36 Private Universities. Hence, this study purposively examined the perception of Nigerian lecturers on usefulness, ease of use and adequacy of use of digital technologies for research based on university ownership.

\section{Statement of the Problem}

Academic productivity of lecturers in the university is measures mostly through research publications in the referred journal outlets in the 21st century. Quality research outputs cannot be achieved without the use of information and communication technologies (Nwokike \& Chiemeka, 2011; Rajasingham, 2010). Hence, the common parlance of publish or perish have been a major concern to academic staff in the universities. In this era of globalization, university lecturers cannot be divorced from usefulness, ease of use and adequacy of use (level of digital proficiency) of digital mobile technologies in facilitating quality academic output in terms of publication. However, some university lecturers do not recognize the opportunities embedded in the use of digital mobile technologies for improving skills, efficiency and effectiveness of instructional delivery, conduct of research and 


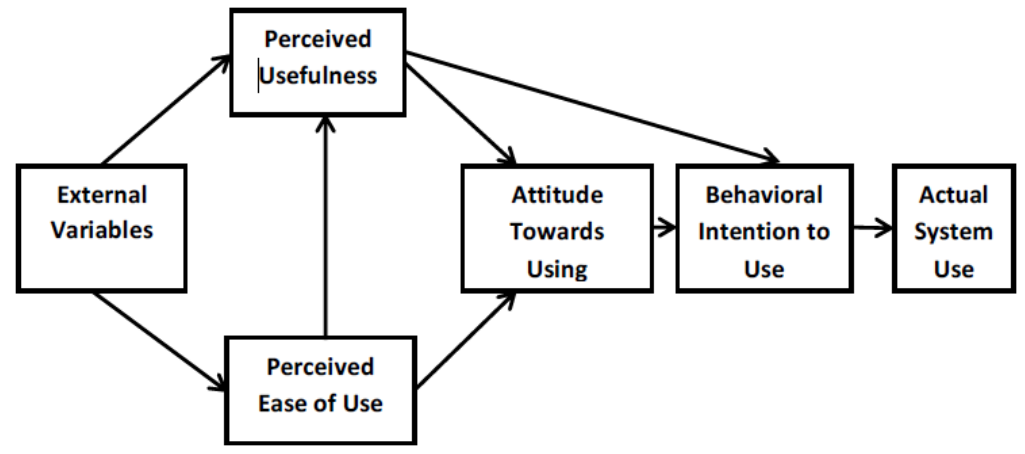

Figure 2. Technology Acceptance Model (TAM)

Source: Technology Acceptance Model (Adapted from Davis, Bagozzi, \& Warsaw, 1989)

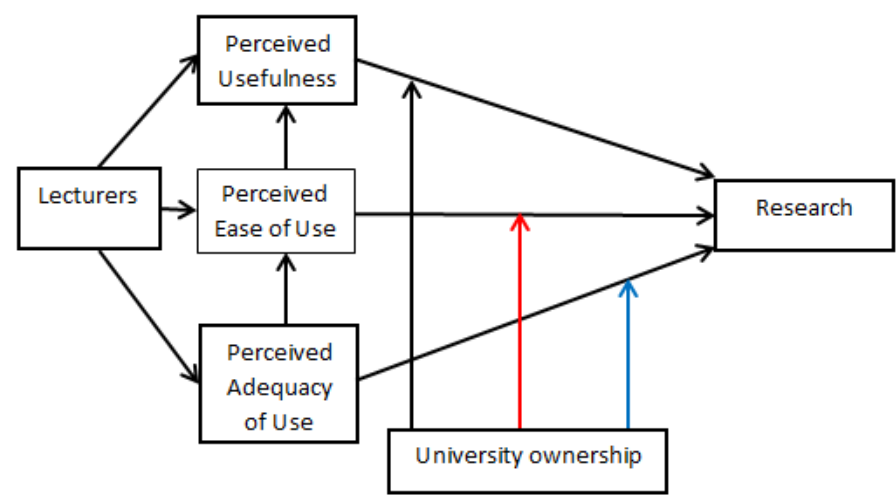

Figure 3. Modified Technology Acceptance Model

Source: Modified Technology Acceptance Model by (Samuel, 2016)

publication irrespective of their university ownership. Similarly, Agber and Agwu (2013) found out that the use digital technologies facilitate academic stat productivity; however, there was difference in the lecturers' frequency of access and use of electronic resources for research. Halidu (2015) observed that acute shortage of fund and research facilities in Nigerian public universities has grossly affect research publication despite their usefulness, ease of use and adequacy of their usage for the conduct of research. Previous studies revealed that access to Information and Communication Technologies had great impact on the productivity of the academic staff (Okafor, 2011); but not on the domain of using standard model as a guide to assess the use of digital technologies in facilitating research based on lecturers' university ownership.

Several studies have been conducted on the use of Technology Acceptance Model (TAM) in various field of endevour. Davis (1989) and Davis, Bagozzi, and Warshaw (1989) modified TRA to expanciate on the users' acceptance or rejection of information technology. Technology Acceptance Model (TAM) was considered as an extension of theory of reasoned action (TRA) (Ajzen \& Fishbein, 1980); as TAM was originally proposed by Davis (1986); as proven theoretical model that explains and predicts users' behavior towards usage, perceived usefulness and ease of use of information technologies (Venkatesh \& Davis, 2000). Figure 2 shows the Technology Acceptance Model (Davis, Bagozzi, \& Warsaw, 1989).

TAM has perceived usefulness and ease of use technology to predict user attitude to the use of information technology in order to measure user acceptance (Zhao \& Wang, 2020). Application of Technology Acceptance Model in studies related to teaching, learning and research has become new development of accepting, adopting or invariably rejecting (Al-Emran, Mezhuyev, \& Kamaludin, 2018) the process of knowledge accessing dissemination and application of original TAM in the field of education (Farahat, 2012), extended TAM with other relevant constructs in determining users' intentions towards using elearning technology (Abdullah \& Ward, 2016; Weerasinghe \& Hindagolla, 2017) and necessity for deploying digital technologies into educational settings (Scherer, Siddiq, \& Tondeur, 2019). Zhao and Wang (2020) extended Technology Acceptance Model (TAM) by incorporating constructs like intrusiveness, social interaction, informativeness on perceived usefulness and perceived ease of use of short-video social media for health advertisement. A study conducted by Samuel, Onasanya, and Olumorin (2018) extended TAM and the findings revealed that university lecturers generally had positive perception toward usefulness, ease of use and adequacy of use of mobile technologies; however, moderating variable was not included in the conduct of the research. Park, Son, and Kim (2012) asserted that appropriate construct can be chosen to predict acceptance, adoption or rejection of using a system vis-à-vis a standard model used like TAM. Based on this assertion, perceived adequacy of use was added construct to the original TAM developed by Davis, Bagozzi and Warshaw (1989). Perceived adequacy has to do tendency of skillfully using the digital technologies effectively to accomplish a task with minimum error (Gardner \& Amoroso, 2004; Samuel, Onasanya, \& Olumorin, 2018). However, attitude to use and behavioural intention to use digital technologies are constructs that were deliberately excluded from original TAM in order to facilitate the researcher to capture the perceived adequacy of use in the study. Hence, this study purposively investigated the perception of Nigerian lecturers on usefulness, ease of use and adequacy of use of digital technologies for research based on university ownership. 


\section{Purpose of the Study}

This study investigated the perception of university lecturers on the use of digital technologies for research in the South-west Nigeria. Specifically, this study examined the university lecturers' perceived usefulness, ease of use and adequacy of use of digital technologies for research based on university ownership.

\section{Research Questions}

The following research questions were answered in the study:

1. Is there any difference between federal and state-owned university lecturers' perceived usefulness of digital technologies for research based on university ownership?

2. What is the difference that exists between federal and stateowned university lecturers' perceived ease of use of digital technologies for research based on university ownership?

3. What are the differences that exist between federal and stateowned university lecturers' perceived adequacy of use of digital technologies for research based on university ownership?

\section{Research Hypotheses}

The following null hypotheses were tested in this study:

Ho1: There is no significant difference in lecturers' perceived usefulness of use of digital technologies for research based on the university ownership.

Ho2: There is no significant difference in lecturers' perceived ease of use of digital technologies for research based on the university ownership.

Ho3: There is no significant difference in lecturers' perceived adequacy of use of digital technologies for Research based on the university ownership.

\section{MATERIALS AND METHODS}

\section{Sample and Sampling Technique}

Sample: state and federal university lecturers in South-west Nigeria were purposively sampled for this study. The South-west universities are situated in Ekiti, Ondo, Lagos, Osun, Ogun and Oyo, which is a geopolitical zone in Nigeria. This is a descriptive research of the survey type. A total of Seven hundred and forty-two (742) lecturers were randomly sampled from 13 purposively sampled universities in the South-western Nigeria.

Instrumentation: structured questionnaire was used the research instrument to collect response on perception of university lecturers on the use of digital technologies for research. A total of 742 out of 1013 copies of the research instruments were retrieved from the sampled universities. Lecturers' university ownership was stratified as state and federal universities. Items on perception of university lecturers on the use of digital technologies for research were structured to elicit responses from the respondents based on Likert rating scale of Strongly Agreed (SA), Agreed (A), Disagreed (D) and Strongly Disagreed (SA). The research instrument was validated by 3 educational technologists and the reliability indices of $\mathrm{r}=0.92,0.85$ and 0.83 using Cronbach Alpha was attained on perceived usefulness, ease of use and adequacy of use of digital technologies respectively for research at 0.05 level of significance. The data generated were analyzed using descriptive and inferential statistics. Research questions 1, 2, and 3 were analyzed using
Table 3. Responses on Lecturers' Perceived Usefulness of Digital Technologies for Research

\begin{tabular}{ccccc}
\hline $\begin{array}{c}\text { University } \\
\text { Ownership }\end{array}$ & Freq. & Percent (\%) & $\begin{array}{c}\text { Sum of mean } \\
\text { for PU }\end{array}$ & Mean (x) \\
\hline Federal & 470 & 63.30 & 42.05 & 3.23 \\
\hline State & 272 & 36.70 & 41.23 & 3.17 \\
\hline Total & 742 & 100.00 & & \\
\hline
\end{tabular}

Note: the average mean for perceived usefulness based on lecturers university ownership was 3.20

Table 4. Responses on Lecturers' Perceived Ease of Use of Digital Technologies for Research

\begin{tabular}{ccccc}
\hline $\begin{array}{c}\text { University } \\
\text { Ownership }\end{array}$ & Freq. & Percent (\%) & $\begin{array}{c}\text { Sum of mean } \\
\text { for PEOU }\end{array}$ & Mean (x) \\
\hline Federal & 470 & 63.30 & 48.92 & 3.26 \\
\hline State & 272 & 36.70 & 48.81 & 3.25 \\
\hline Total & 742 & 100.00 & & \\
\hline
\end{tabular}

Note: the average mean for perceived ease of use of digital technologies based on lecturers' gender was 3.26

frequency counts, means and percentages; while t-test statistical instrument was used to test hypotheses 1,2 and 3 on university lecturers' perceived usefulness, ease of use and adequacy of use of digital technologies respectively at 0.05 level of significance.

\section{RESULTS}

Research question 1: Is there any difference between federal and state-owned university lecturers' perceived usefulness of digital technologies for research based on university ownership?

Table 3 shows the lecturers' responses on perceived usefulness of digital technologies for research based on the university ownership. Table 1 showed that $470(63.30 \%)$ federal and 272 (36.70\%) state university lecturers were involved in the study. The mean score of lecturers from federal and state government owned universities for perceived usefulness of digital technologies for research were 3.23 and 3.17 , respectively, while the average mean score was 3.20 out of 4.00 . Considering the benchmark of 2.5, the high mean score (3.20) showed that lecturers from both federal and state government owned universities perceived digital technologies to be useful for research. However, the high means scores (3.23) of perceptions of lecturers from federal government owned universities exemplified their high perceived usefulness of digital technologies for research than their counterparts from state (3.17) owned universities as shown in Table 1. Therefore, difference in perception existed among the university lecturers on perceived of usefulness of digital technologies for research based on university ownership.

Research question 2: what is the difference that exists between federal and state-owned university lecturers' perceived ease of use of Digital technologies for Research based on their university ownership?

Table 4 shows the lecturers responses from federal and state government owned universities on the perceived ease of use of use of digital technologies for research. The mean scores of lecturers' perceptions from federal and state government owned universities on ease of use of digital technologies for research were 3.26 and 3.25, respectively, while the average mean score was 3.26 . Considering the benchmark of 2.5 , high average mean score of 3.26 out of 4.00 
Table 5. Responses of Perceived Adequacy of Use of Digital technologies for Research

\begin{tabular}{ccccc}
\hline $\begin{array}{c}\text { University } \\
\text { Ownership }\end{array}$ & Freq. & Percent (\%) & $\begin{array}{c}\text { Sum of mean } \\
\text { for PEOU }\end{array}$ & Mean (x) \\
\hline Federal & 470 & 63.30 & 41.14 & 3.43 \\
\hline State & 272 & 36.70 & 41.77 & 3.48 \\
\hline Total & 742 & 100.00 & & \\
\hline
\end{tabular}

Note: the average mean for perceived adequacy of use of Digital technologies based on lecturers' gender was 3.46

Table 6. Independent t-test of University Lecturers' Perceived Usefulness of Digital Technologies for Research

\begin{tabular}{cccccccc}
\hline $\begin{array}{c}\text { University } \\
\text { Ownership }\end{array}$ & Freq. & $\mathbf{X}$ & SD & df & t & $\begin{array}{c}\text { Sig.(2- } \\
\text { tailed) }\end{array}$ & Remark \\
\hline Federal & 470 & 42.05 & 4.04 & & & & \\
\hline & & & & 740 & 2.84 & 0.01 & Rejected \\
\hline State & 272 & 41.23 & 3.55 & & & & \\
\hline Total & 742 & & & & & & \\
\hline
\end{tabular}

exemplified strong affirmations by the university lecturers that digital technologies are easy to use for research irrespective of lecturers' residents' place (university ownership) of appointment - either federal or state government owned university. However, as shown in Table 4, a slightly high mean score for federal (3.26) government owned lecturers exemplified the affirmation that digital technologies are easy to use for research than their counterparts from state (3.25) owned universities. The study inferred that lecturers' perceived ease of use of digital technologies for research differently based on their university ownership.

Research question 3: What are the differences that exist between federal and state-owned university lecturers' perceived adequacy of use of digital technologies for research based on university ownership?

Table 5 shows the lecturers' responses on the perceived adequacy of use of digital technologies for research based on the university ownership. As contained in Table 3, the mean scores of lecturers from federal and state government owned universities for perceived adequacy of use of digital technologies for Research are 3.43 and 3.48, respectively, while the average mean score was 3.46 . Considering the benchmark of 2.5 , the high average mean score of 3.46 out of 4.00 demonstrates that the university lecturers strongly affirmed using digital technologies to accomplish research task effectively with minimum error; irrespective of lecturers' residents' place (university ownership) of appointment - either federal or state government owned university. However, lecturers from state (3.48) government owned universities perceived adequacy of use of digital technologies for accomplishing research task effectively with minimum error slightly higher than their counterparts from federal (3.43) government owned universities.

\section{Hypotheses Testing}

Ho1: There is no significant difference in lecturers' perceived usefulness of digital technologies for Research based on university ownership.

Table 6 showed the respondents analyzed data on perceived usefulness of digital technologies for research based on university ownership using independent $t$-test statistical instrument. Table 6 reveals that $t(740)=2.84, \mathrm{p}=0.01(\mathrm{p}<0.05)$ for lecturers perception on
Table 7. Independent t-test of University Lecturers' Perceived Ease of Use of Digital Technologies for Research

\begin{tabular}{cccccccc}
\hline $\begin{array}{c}\text { University } \\
\text { Ownership }\end{array}$ & Freq. & $\mathbf{X}$ & SD & df & t & $\begin{array}{c}\text { Sig.(2- } \\
\text { tailed) }\end{array}$ & Remark \\
\hline Federal & 470 & 48.92 & 3.60 & & & & \\
\hline & & & & 740 & 0.44 & 0.66 & $\begin{array}{c}\text { Not } \\
\text { rejected }\end{array}$ \\
\hline State & 272 & 48.81 & 3.46 & & & & \\
\hline Total & 742 & & & & & & \\
\hline
\end{tabular}

the usefulness of digital technologies for research. The implication is that the result of $t$-value of 2.84 resulting in 0.01 significant value was less than 0.05 alpha value. The stated null hypothesis was rejected. The stated null hypothesis was established as: there was significant difference in lecturers' perceived usefulness of digital technologies for research based on university ownership (federal and state university). The analysis revealed that federal government owned universities lecturers' mean score (42.05) on perceived usefulness of digital technologies for research was slightly higher than their counterparts in the state-owned universities (41.23). Thus, lecturers from federal universities perceived the use of digital technologies to be useful for research more than lecturers in the state universities. The implication is that the university lecturers perceived the usefulness of digital technologies differently for research based on their university ownership.

Ho2: There is no significant difference in lecturers' perceived ease of use of Digital technologies for Research based on their university ownership.

Table 7 showed the respondents analyzed data on perceived ease of use of digital technologies for research based on university ownership using independent $t$-test statistical instrument. Table 7 revealed that $t$ $(740)=0.44, p=0.66(p>0.05)$ of lecturers perceptions on ease of use of digital technologies for research. The implication is that the results of $\mathrm{t}$-value of 0.44 resulting in 0.66 significant value was greater than 0.05 alpha value. This also implies that .66 was considered for the sig.(2tailed) of the independent $t$-test for equality which shows that there was no significant difference in the mean scores (since sig.(2-tailed) was greater than 0.05). The stated null hypothesis was not rejected. The stated null hypothesis was established as: there was no significant difference between federal and state university lecturers' perceived ease of use of digital technologies for research based on university ownership. Subsequently, the mean score (48.92) for federal government owned universities lecturers' on perceived ease of use of digital technologies was slightly higher than their counterparts in the state owned universities (48.81). Thus, lecturers from federal universities perceived digital technologies not to be difficult to use in the conduct of research compared with their counterparts in the stateowned universities.

Hoz: There is no significant difference in lecturers' perceived adequacy of use of Digital technologies for Research based on their university ownership.

Table 8 showed the respondents analyzed data on perceived adequacy of use of digital technologies for research based on university ownership using independent $t$-test statistical instrument. Table 8 revealed that $t(740)=-2.71, \mathrm{p}=0.01(\mathrm{p}<0.05)$ for lecturers' perceived adequacy of use of digital technologies for research. The result of the tvalue of -2.71 resulting in 0.01 significant value was less than 0.05 alpha 
Table 8. Independent t-test of University Lecturers' Perceived Adequacy of Use of Digital technologies for Research

\begin{tabular}{cccccccc}
\hline $\begin{array}{c}\text { University } \\
\text { Ownership }\end{array}$ & Freq. & $\mathbf{X}$ & SD & df & t & $\begin{array}{c}\text { Sig.(2- } \\
\text { tailed) }\end{array}$ & Remark \\
\hline Federal & 470 & 41.15 & 3.28 & & & & \\
\hline & & & & 740 & -2.71 & 0.01 & Rejected \\
\hline State & 272 & 41.77 & 2.45 & & & & \\
\hline Total & 742 & & & & & & \\
\hline
\end{tabular}

value. The stated null hypothesis was rejected and was established as: there was no significant difference between federal and state university lecturers' perceived adequacy of use of digital technologies for research based on university ownership. The mean scores of lecturers from state (41.77) owned universities was slightly higher than the mean score (41.15) of their counterparts in the federal government owned universities. Thus, the analysis revealed that lecturers from state and federal universities differ in perceptions of adequacy of use of digital technologies for research in favour of lecturers in the state-owned universities.

\section{DISCUSSIONS}

The findings of this study agreed with Samuel (2016) and Samuel, Onasanya and Olumorin (2018) that the usefulness of newer digital technologies more often encourage speedy dissemination research findings in form of research publications anywhere and anytime; efficient production of competences and employability skills for effective job delivery that will facilitate national development and growth (Udoh-Uwah \& Etim, 2018) via research publications. Similarly, the findings of this study agreed with Ogunjobi and Fagbami (2012) that the usefulness of digital technologies and internet facilities are capable of providing Nigerian researchers and scholars with the enabling environment (ease of use) of overcoming obstacles to communication and collaboration (adequacy of use) and presentation of research findings with ease across the globe. The findings of the study agreed with Rajasingham (2010), and Nwokike and Chiemeka (2011) that the usefulness, ease of use adequacy of digital technologies facilitates the production of quality research outputs. Hence, the conventional parlance of "publish or perish" among the academic staff in the universities; motivated attaching high regard to the usefulness, ease of use and adequacy of use (digital proficiency) to the use of digital mobile technologies in facilitating quality academic output termed publication. The usefulness, ease of use and adequacy of use of use of digital technologies agreed with Abba and Lamido - Gora (2019) that avid thirst to increase university lecturers' proficiency on the use of digital and internet facilities for dissemination of academic finding via publication made the lecturers to find the usage of digital technologies easy and adequate. In summary, this study agreed with Samuel, Onasanya and Olumorin (2018) the use of newer technologies to access and disseminate research findings becomes very paramount tools to university academic staff in the 21 st century system of education. Hence, university lecturers generally had positive perception toward usefulness, ease of use and adequacy of use of mobile technologies in facilitating the conduct of research irrespective of their university ownership.

\section{CONCLUSION}

The avid thirst for knowledge and dissemination of findings via digital technologies in facilitating the conduct of research motivated the university lecturers to employ their usage in order to overcome the common parlance of "publish or perish" in academic community. The use of newer digital technologies facilitates speedy access and dissemination research findings in form of research publications anywhere and anytime. Hence, this study adapted the use of standard model from original TAM (Davis, Bagozzi, \& Warshaw, 1989) to incorporate perceived usefulness, ease of use and adequacy of use of digital technologies for research. Perceived adequacy is the tendency to skillfully use digital technologies effectively to accomplish a task with minimum error (Samuel, Onasanya, \& Olumorin, 2018).

Considering the benchmark of 2.5, federal government owned university lecturers exemplified high perception on the usefulness and also found digital technologies very easy to use for research than their counterparts from state universities due funding and better remuneration enjoyed in their respective universities. However, lecturers from state government owned universities perceived adequacy of use of digital technologies for accomplishing research task effectively with minimum error than their counterparts in the federal government owned universities. The usefulness of digital technologies and internet facilities are capable of providing tutors, researchers and scholars with an enabling environment (ease of use) of overcoming obstacles to communication and collaboration (adequacy of use), accomplish research task effectively with minimum error; presentation of research findings with ease across the globe irrespective of lecturers' residents' place (university ownership) of appointment - either federal or state government owned university.

\section{RECOMMENDATIONS}

The study recommends that:

1. Adequate fund and intensive seminar should be organized for lecturers in the state-owned universities in order to motivate them attached importance to the use of digital technologies for research.

2. Adequate digital technologies should be procured to state owned university lecturers, coupled with seminars, workshops and trainings on how to use digital technologies with ease in the conduct of research and publication.

3. Intensive seminars, workshop and trainings should be organized for the lecturers in the federal government owned universities on how to skillfully use of digital technologies for accomplishing research task effectively with minimum error.

4. University administrators should endeavour to provide adequate institutional support, procurement of the needed digital technologies and internet facilities, seminars, workshops and trainings to all university lecturers on usefulness, ease of use of newer digital technologies and skills to possess in accomplishing research task effectively with minimum error; irrespective of university ownership.

Author contributions: All authors were involved in concept, design, collection of data, interpretation, writing, and critically revising the article. All authors approve final version of the article. 
Funding: The authors received no financial support for the research and/or authorship of this article.

Declaration of interest: Authors declare no competing interest.

Data availability: Data generated or analysed during this study are available from the authors on request.

\section{REFERENCES}

Abba, T., \& Lamido-Gora, A. (2019). University Lecturers' Level of Awareness and Proficiency of Internet Services and Resources for Academic Activities in Adamawa State, Nigeria, Library Philosophy and Practice, 1-18.

Abdullah, F., \& Ward, R. (2016). Developing a General Extended Technology Acceptance Model for E-Learning (GETAMEL) by analyzing commonly used external factors. Computers in Human Behavior, 56, 238-256. https://doi.org/10.1016/j.chb.2015.11.036

Agber, T., \& Agwu, E. A. (2013). Assessment of online resources usage by agricultural science lecturers of tertiary institutions in Benue state, Nigeria, American Journal of Research Communication, 1(10), 254-279. www.usa-journals.com

Ajzen, I., \& Fishbein, M. (1980). Understanding attitudes and predicting social behavior. Prentice- Hall.

Al-Emran, M., Mezhuyev, V., \& Kamaludin, A. (2018). Technology Acceptance Model in M-learning context: A systematic review. Computers \& Education, 125, 1-41. https://doi.org/10.1016/ j.compedu.2018.06.008

Davis, F. (1989). Perceived usefulness, perceived ease of use, and user acceptance of information technology. Management of Information Science Quarterly, 13(3), 319-340. https://doi.org/10.2307/249008

Davis, F. D., Bagozzi, R. P., \& Warshaw, P. R. (1989). User acceptance of computer technology: A comparison of two theoretical models. Management Science, 35, 982-1002. https://doi.org/10.1287/ mnsc.35.8.982

Famurewa, I. O. (2014). Inadequate funding as the bane of tertiary education in Nigeria. Greener Journal of Economics and Accountancy, 3(2), 25-33. https://doi.org/10.15580/GJEA.2014.2.0515014237

Farahat, T. (2012). Applying the Technology Acceptance Model to Online Learning in the Egyptian Universities. Procedia - Social and Behavioral Sciences, 64, 95-104. https://doi.org/10.1016/ j.sbspro.2012.11.012

Gardner, C., \& Amoroso, D. L. (2004). Development of an Instrument to Measure the Acceptance of Internet Technology by Consumers, Proceedings of the 37th Hawaii International Conference on System Sciences. San Diego State University 5500 Campanile Drive San Diego, CA, 1-10. https://doi.org/10.1109/ HICSS.2004.1265623

Halidu, S. G. (2015). Assessment of funding of federal universities in Nigeria: Evidence from Ahmadu Bello University. Yobe Journal of Economics (YOJE), 2(1), 272-283.

Mogaji, E. (2019). Types and Location of Nigerian Universities. Research Agenda Working Papers. 7, 92-103. https://doi.org/ 10.31124/advance.9722618
National Universities Commission (NUC). (2019). Home. [Online] http://nuc.edu.ng/

Nwokike, O., \& Chiemeka, I. P. (2011). Perceived readiness of teachers form online education in the University of Ibadan, Oyo state, Nigeria. Journal of Education and Practice, 2(7), 1-10. www.iiste.org

Ogunjobi, T. E., \& Fagbami, O. O. (2012). Use of the internet by researchers in agricultural research institutes in Ibadan, Oyo State. International Journal of Library and Information Science, 4(4), 52-56. https://doi.org/10.5897/IJLIS11.068

Okafor, V. N. (2011). Research output of academics in the science and engineering faculties of the federal universities in Southern Nigeria. African Journal of Library, Archives and Information Science, 20(1), 4151.

Park, Y., Son, H., \& Kim, C. (2012). Investing the determinants of construction professional acceptance of web-based training: An extension of the technology acceptance model. Automation in Construction, 22, 377-386. https://doi.org/10.1016/j.autcon.2011. 09.016

Rajasingham, L. (2010). Will mobile learning bring a higher education? Education Research International, 2011, Article ID 528495. https://doi.org/10.1155/2011/528495

Samuel, N. (2016). University lecturers' perceptions of the use of mobile technologies for research collaboration in South-west, Nigeria (Doctoral thesis), Educational Technology at the Department of Educational Technology University of Ilorin, Kwara State, Nigeria.

Samuel, N., Onasanya, S. A., \& Olumorin, C. O. (2018). Perceived usefulness, ease of use and adequacy of use of Digital technologies by Nigerian university lecturers. International Journal of Education and Development using Information and Communication Technology (IJEDICT), 14(3), 5-16.

Scherer, R., Siddiq, F., \& Tondeur, J. (2019). The technology acceptance model (TAM): A meta-analytic structural equation modeling approach to explaining teachers' adoption of digital technology in education. Computers \& Education, 128, 13-35. https://doi.org/10.1016/j.compedu.2018.09.009

Udoh-Uwah, O. E., \& Etim, M. E. (2018). Professional Development and Lecturers' Job Effectiveness in Universities in South-South Geo-Political Zone of Nigeria, Journal of Education and Practice, 9(12), 123-128.

Venkatesh, V., \& Davis, F. D. (2000). A theoretical extension of the technology acceptance model: Four longitudinal field studies, Management Science, 46(2), 186-204. https://doi.org/10.1287/ mnsc.46.2.186.11926

Weerasinghe, S., \& Hindagolla, M. (2017). Technology Acceptance Model in the Domains of LIS and Education: A Review of Selected Literature. Library Philosophy \& Practice, 1-26.

Zhao, J., \& Wang, J. (2020). Health advertising on short-video social media: a study on user attitudes based on the extended technology acceptance model, International Journal of Environmental Research and Public Health, 17, 1-21. https://doi.org/10.3390/ijerph17051501 